\title{
Age-based variation and patterns of recent language change: a case-study of morphological and lexical intensifiers in Spanish
}

\section{Linde Roels, Renata Enghels - Universiteit Gent}

\section{Abstract}

This study aims to gain further insight into processes of recent language change, both at the level of the speech community and the individual one (i.e. in terms of age-grading), by combining the Real-Time Construct and the Apparent-Time Construct. It focuses on intensifiers, which are of a particular interest due to their versatility and rapid change. The data are collected in a corpus of Madrilenian present-day Spanish (CORMA), and provide an overview of synthetic intensifying constructions, including suffixation (e.g. golazo 'nice goal') and prefixation (e.g. superguay 'very cool') of the base, and several analytic constructions, that is lexical intensifiers that modify a base-word (e.g. mazo de humilde 'really humble'). In concrete, the productive paradigm of intensifying strategies is empirically monitored across different generations. This analysis leads to a deeper understanding of the distribution and motives behind age-based preference, and unveils whether the Apparent-Time Construct is able to equally detect recent language change for different linguistic features.

\section{Keywords}

age-based variation, recent language change, Apparent-Time Construct, Real-Time Construct, intensification, colloquial Spanish, corpus linguistics

\section{Introduction}

Processes of language change can be monitored by applying different methodologies, namely by conducting a Real-Time Analysis or an Apparent-Time Analysis (Blas Arroyo, 2005; Bowie, 2005; Díaz-Campos, 2014; Meyerhoff, 2011; Silva-Corvalán, 2001). When conducting a Real-Time Analysis, one compares the speech of a constant group of speakers (although, in practice, these are often speakers with comparable extra-linguistic characteristics and background) over different time periods, resulting in a longitudinal study. This approach involves the exploration of highly comparable data which, however, are hard to find. On the other hand, in an Apparent-Time Analysis, a linguistic phenomenon is analyzed across the speech of different generations during one and the same time period (Bailey et al., 1991). The basic assumption of this construct is that linguistic differences between generations mirror developments in language. It assumes that the speech of people in a particular age group is largely fixed before adulthood and remains quite stable throughout the speakers' adult life. As a consequence, the language of older generations are treated as a proxy for language use at an earlier stage. So, in a contemporary corpus, the use of a particular linguistic item can be compared across different generational groups in order to describe its former uses (e.g. Levey (2008) on the English marker like, or Wieling et al. (2016) on hesitation markers such as um). 
Numerous sociolinguistic studies have demonstrated the worth of the Apparent-Time Construct (e.g. Bailey et al., 1991). It has for instance been successfully applied to the study of changes in the English intensifying system (Tagliamonte, 2008). However, it has also been subject to critical assessments. First, the hypothesis that adult vernaculars remain stable across speakers' life has been debated. As an alternative to the idea that the speech of a fourth generation speaker reflects language use of say fifty or sixty years ago, the concept of agegrading has been proposed. This involves that individuals adopt certain changes in their speech as they grow older, and as such account for speech-community wide changes (Bowie, 2005; Wagner, 2012). Second, few studies have empirically monitored whether the ApparentTime Construct is able to detect recent language change for different linguistic features - that is, of various formal and semantic nature - in the same way. The present study aims to bridge this knowledge gap by applying a cross-over of both the methodologies of Real-Time Analysis and Apparent-Time Analysis to the study of Spanish intensifiers.

It is well known that intensifying strategies, characterized by versatility, are of a particular interest for the study of language change ${ }^{1}$. Intensifiers thrive on semantic innovation, their impact and expressive power being only as good as their novelty (Lorenz, 2002; MéndezNaya, 2008; Tagliamonte, 2008). This feature ensures that speakers constantly renew intensifying expressions. As stated by König (2017: 15), even within the life span of one generation, processes of obsolescence (e.g. vachement, bougrement in French) and renewal (e.g. additions to the inventory of brutal in German, some in English, carrément in French) can be observed. And this is particularly the case within the speech of younger generations as linguistic innovators. Indeed, the factor of age turns out to be an important factor for the study of language change. As stated before, age and intergenerational linguistic behavior have a key function in the Apparent-Time Construct. In the present study, the age of a speaker is not only conceived in a strict biological sense, but as the integration of a speaker within a particular age-group with common life-experiences, shared habits and networks ${ }^{2}$. For instance, teenagers stand out for their desire to create in-group membership, both culturally and linguistically (Lorenz, 2002), and for their generation-specific digital abilities. Interestingly, intensification has received wide attention in the study of generation-specific language use (Barbieri, 2008; Blas Arroyo, 2005). Studies on the English intensifier system at the turn of the $21^{\text {st }}$ century have even pointed to a spectacular 'generation gap' in the use of intensifiers (Bauer \& Bauer, 2002; Ito \& Tagliamonte, 2003; Paradis, 2000; Tagliamonte, 2008).

Against this background of language change and generation-specific language use, the present study focuses on the highly productive paradigm of intensifying strategies in

\footnotetext{
${ }^{1}$ In terms of Stenström (2005: 206), intensifiers belong to the category of words "with the most rapid turnover".

2 It goes without saying that age interacts with other social factors such as gender, social class, family state, working place etc. (e.g. Cameron's study on aging and gendering (2005)). However, the focus of this study is exclusively on age, being a crucial variable for the implementation of the Apparent-Time Construct.
} 
contemporary Madrilenian Spanish. Recent decades have witnessed a growing interest in the study of Spanish intensifying strategies, not only from a more descriptive point of view (Albelda Marco, 2007; Arce Castillo, 1999; Briz Gómez, 1996; Herrero Moreno, 1991) but also as regards specific intensifying mechanisms (e.g. Fuentes Rodríguez, 2006; Martínez López, 2009; AUTHOR). There also have been several attempts to empirically study quantitative tendencies and sociolinguistic preferences in the alternating use of intensifiers by teenagers (Molina Martos, 2010; Palacios \& Núñez, 2014; Stenström, 2005). Still, these studies are based on data of the beginning of the $21^{\text {st }}$ century. Given the fact that the paradigm of intensifying mechanisms becomes quickly outdated, more recent corpus-based studies on the rapidly changing paradigm of intensifying mechanisms are urgently called for.

In line with these considerations, this article pursues a triple goal. First, it provides an overview of a set of morphological and lexical uses in a corpus of present-day Madrilenian Spanish, and as such offers an updated version of current intensifying strategies. Second, it provides insights into the relationship between the use of a particular intensification strategy and the sociolinguistic variable of the age of speakers. The comparison of intensifying mechanisms between different generations may lead to a deeper understanding of the distribution and motives behind age-based preferences. Finally, by combining the Real-Time Construct and the Apparent-Time Construct, the study aims to gain further insight into the processes of linguistic change to which intensifiers are subject. The method allows to test whether the applicability of the Apparent-Time Construct depends on the nature (e.g. morphological versus lexical device) of the linguistic element under investigation. It therefore looks into the use of two distinctive members of the paradigm, namely the lexical item mazo and the intensifying prefix super-.

The remainder of this article is structured as follows. Section 2 reviews the notion of intensification and explains why this study focuses on lexical and morphological intensifying mechanisms. Section 3 provides more information on the data and the research methodology. Section 4 presents the results of a detailed corpus analysis and focuses on the formal variation of intensifiers. Section 5 further elaborates on age-based variation and examines the influence of the age of the speakers on the varying use of specific intensifying devices. Section 6 analyzes recent patterns of language change of two specific intensifiers, mazo and super-. The methodology applied for this study consists in a cross-over between the Real-Time Construct and the Apparent-Time Construct. Section 7 discusses these results and presents some concluding remarks.

\section{Preliminary considerations on intensification}

The expression of intensification is a universal concept, available in most, if not all, languages in great abundance (Bolinger, 1972; König, 2017). Besides through embodied 
communication (i.e. gestures or facial expressions) and suprasegmental features (Bonacchi, 2017), speakers intensify their language by using several purely linguistic strategies, operating at different levels ${ }^{3}$. Following Grandi (2017), this study defines intensification as a semanticfunctional operation realized by different linguistic strategies. As such, it analyzes the alternating use of different morphological and lexical means that perform the same semantic operation ${ }^{4}$. These intensifying strategies or intensifiers can modify the propositional content of the base, from a quantitative or qualitative point of view (Arce Castillo, 1999; Briz Gómez, 1996; Napoli \& Ravetto, 2017). In (1a), the prefix super- and the binominal quantifier un montón de ('a heap of') underline the quantity of the modified elements, by highlighting respectively the length of the table and the amount of people. In (1b) by using the prefix super-, the speaker underlines the quality of Ana being really happy. In concrete, Grandi (2002: 32) distinguishes between two main semantic and conceptual spaces: the descriptive/quantitative dimension as in (1a), based on the opposition between the semantic primitives BIG/SMALL and the qualitative dimension, as illustrated in (1b), characterized by the dichotomy of GOOD/BAD.

(1a) PEL3F2 Luego cuando voy al otro digo <Anda míralo si está aquí este hombre en una mesa super larga con un montón de gente $>^{5}$ ('Later when I went to the other one I said $<$ go ahead, look if this man is here at a very long table with a heap of people>.')

(1b) AM3F2 Y Ana está super contenta eh ('And Ana is really happy, eh.')

However, intensifiers cannot only be accounted for in terms of degree modification. As a complex conversational phenomenon, intensification goes beyond the boundaries of semantic gradability and attests increasing subjectivity and expressive strength (Fiorentini \& Sansò, 2017; Napoli \& Ravetto, 2017).

Indeed, intensifiers are subjective and pragmatically-driven by definition since their use implies an evaluation on behalf of the speaker, who expresses his/her personal attitude, emotion or opinion with regard to an observed entity, quality or event (Athanasiadou, 2007; Dressler \& Merlini Barbaresi, 1994; Napoli \& Ravetto, 2017). This personal evaluation can be conceived of as a shift towards the positive or negative end of the (semantic) scale of intensification, ranging from disapproval to appreciation. Hence, besides the more traditional quantitative and/or qualitative dimensions of intensification, the present study also considers cases in which the intensifier relates to a specific negative or positive evaluation of an intensified base. In case (2a), the speaker mentions a "shitty task" instead of the more neutral

\footnotetext{
${ }^{3}$ A thorough analysis of these non-verbal expressions within the Spanish culture would be highly interesting, but falls outside the scope of this study.

${ }^{4}$ In order to be able to systematically track age-based variation and patterns of recent language change, the analysis focuses on morphological and lexical strategies, leaving for future investigation the analysis of the syntactic, pragmatic, prosodic and textual level.

${ }_{5}$ All examples cited in this article are taken from the Corpus Oral de Madrid (CORMA) (cf. Section 3 for more details).
} 
option of an "unpleasant" task. The evaluation of the task is thus qualitatively loaded with respect to a reference point, with a shift towards the negative end of the scale. Contrary to this pejorative meaning, que te cagas, which, however, originated in the same taboo field ${ }^{6}$, acquires a positive meaning in the broader context of $(2 b)^{7}$. These pragmatic values constitute the common denominator of the heterogeneous paradigm of intensifiers (König, 2017: 15; Paradis, 2008).

(2a) AM2M8 Y por fin acabaremos este trabajo de mierda ('And finally we will finish this shitty task.')

(2b) PEL3F2 Sí, sí, mola que te cagas (lit. 'Yes, yes, it's so cool that you shit yourself.'; 'Yes, yes, it's extremely cool.')

This heterogeneity may also apply to a particular language, as is the case of Spanish. Indeed, a contrastive study of the teenage talk of Spanish and English girls (Stenström, 2005) has shown that the Spanish intensification system is a highly productive category, both in terms of type and token frequency. The use of intensifiers by Spanish teenage girls is not only more frequent overall, it is also more varied including, amongst others, adverbs (todo, bien), nouns (mazo), clauses (que te cagas), a superlative suffix (-ísimo/a), etc ${ }^{8}$.

To recap, intensifying strategies can significantly vary in terms of their values, expressivity and productivity. Different intensifiers have neither the same semantic and pragmatic properties nor the same intensifying force, and may be ordered along a 'intensification cline' (Grandi, 2017). This heterogeneity becomes clear when comparing different intensifying strategies: for instance, the English intensifiers very and fucking are different in terms of frequency, origin and expressive power. The same applies in Spanish to the semantically more neutral intensifiers super- (superguay 'really cool') and bien (bien limpio 'well clean') in comparison with more vulgar and expressive forms as puto (lit. 'whore') or que te cagas (cf. example (2b) mentioned above).

In the attempt of creating a comparative framework that can be applied to conversational data of different generations (cf. Section 1), this paper is mainly concerned with a specific subgroup of morphological (i.e. synthetic) and lexical (i.e. analytic) intensifiers. These formal elements can be seen as parts of the "cloud of exemplars" (Bybee, 2010: 14) that Spanish speakers have at their disposal to express the semantic-functional category of intensification. The synthetic structures imply morphological mechanisms, as illustrated by tardísimo in (3).

\footnotetext{
${ }^{6}$ Both intensifiers in (2) originated as taboo words but, due to their repeated use in teen talk, were semantically bleached and lost a good deal of their negative expressive power (Palacios \& Núñez, 2012: 782; Stenström, 2017: 175). However, they remain expressive and colloquial marked intensifiers.

${ }^{7}$ Note that, for the correct interpretation of the examples, we had to refer to the broader context of the CORMA corpus, not shown here because of space restrictions.

${ }^{8}$ As opposed to the inventory of English intensifiers which is realized mostly by adverbs (e.g. really, very, bloody).
} 
Besides evaluative prefixes and suffixes, also lexical analytic devices are considered. For instance, the addition of the lexical intensifier puto in (3) allows the speaker to further strengthen his assertion that he arrived late because of the public transport and add a considerable degree of emotional involvement of anger and frustration.

(3) CON2M1 No porque como he llegado tardísimo por el puto tren que ha tardado cuarenta minutos en vez de veinte ('No because as I arrived really late because of the fucking train that took forty minutes instead of twenty.')

\section{Data and Methodology}

\subsection{Corpus data}

As intensifiers are highly context-dependent (i.e. the same intensifying form may denote different kinds of feelings and attitudes depending on the modified base and on the discursive context), a corpus-based approach is required. The subset of intensifiers were extracted from the Corpus Oral de Madrid (henceforth CORMA). This corpus of peninsular Spanish was compiled by the Ghent University department of Spanish Linguistics to remedy the scarce documentation of $21^{\text {st }}$ century colloquial Spanish (AUTHOR 3). This corpus contains 58 informal conversations between speakers of Madrid. In numeric terms, it includes almost 45 recorded hours, corresponding to 320,401 transcribed words and it represents the speech of 390 speakers $^{9}$. It is characterized by a high degree of both situational and sociolinguistic variation, with a representative number of participants of both sexes, different generations and different socio-economic groups ${ }^{10}$ involved in five different communicative settings (family, friends, customer service, colleagues and acquaintances). As such, the corpus generally embodies a representative mosaic of the Spanish capital's linguistic variety.

Two different methods were applied to elicit the data. In most conversations, the participants were aware of the fact of being recorded. The recordings were made by recruits, or participants responsible for the recording ${ }^{11}$. The recordings were compiled in an unguided manner, meaning that the recruit had a high degree of self-control over the recording circumstances (e.g. participants, duration, activity, topic). In other conversations, the (semi-)secret recording principle was applied and participants were generally not aware of the fact of being recorded.

\footnotetext{
${ }^{9}$ Each speaker received a codified name according to the variables under consideration. The initial letters refer to the communicative context (e.g. $\mathrm{AM}=$ amigos ('friends'), $\mathrm{PEL}=$ peluquería ('hair salon'), the first number gives more information about the generation to which the speaker belongs (e.g. $2=$ Gen2, $3=$ Gen3). The following letter informs about the gender (e.g. $\mathrm{M}=$ male, $\mathrm{F}=$ female) and the last number (e.g. 1 in CON2M1) indicates that the speaker was the first male speaker of the second generation to participate in the recorded conversation among acquaintances ('conocidos').

10 Therefore, the corpus follows the broadly accepted sociolinguistic classification parameters (e.g. Blas Arroyo, 2005; Chambers, 2003).

${ }^{11}$ The recruits had been 'captured' by a contact person in Madrid, who was a mutual friend or acquaintance of one of the members of the academic team. The researcher was not present nor did (s)he have an active role in the conversation.
} 
This is for instance the case of the majority of customer services contexts, since only the owner or person in charge of the business was informed in advance about the recordings. Regardless of the method used, the obtained data are authentic, which is reflected in the often intimate topics, the high dynamicity and cooperative dialogues ${ }^{12}$. The conversations are characterized by the equality between speakers, the familiar discursive scenery, the non-specified conversation topics, the absence of planning and the interpersonal communicative goals. Hence, they may rightly be defined as prototypical colloquial and spontaneous conversations (Briz Gómez, 1998), which are said to favor the appearance of intensifying features.

The CORMA is a highly appropriate corpus for this study for more reasons. As a contemporary corpus, it documents the constantly renewing intensifiers in the present-day Spanish (cf. Section 1). Furthermore, it was recorded in Madrid, and the language variety in the capital usually enjoys great prestige ('the capital's prestige', Jørgensen and Drange, 2012). Linguistic innovations are believed to mostly originate in big cities, from where they spread out to more peripheral areas (Blas Arroyo, 2003). Consequently, we can expect the corpus to document a highly productive and innovative inventory of intensifying forms. In addition, the corpus records the speech of four different generations, and as such enables the implementation of the Apparent-Time Construct (cf. Section 1). Table 1 gives an overview of the number of speakers according to the sociolinguistic class (defined both by age and gender) to which they belong.

\begin{tabular}{|l|l|l|l|}
\hline Generation & \# speakers & Male & Female \\
\hline Gen1 (0-11) & 34 & 16 & 18 \\
\hline Gen2 (12-25) & 48 & 23 & 25 \\
\hline Gen3 (26-55) & 141 & 45 & 96 \\
\hline Gen4 (+55) & 129 & 51 & 78 \\
\hline Total & 352 & 135 & 217 \\
\hline
\end{tabular}

Table 1: Distribution of speakers in CORMA ${ }^{13}$

\footnotetext{
12 In order to comply with the European privacy laws, all the responsible participants had to give their explicit informed consent. Moreover, to safeguard the authenticity of the data, the recruits were not informed about the specific purposes of the composition of the corpus. In most cases the recordings were made with a portable digital recorder (a.o. Tascam DR-40, Philips Voice Recorder DVT 2000, ZOOM H1), but the recruits also had the opportunity to record using their own mobile phone. As a device that is an essential part of modern day life, the use of a mobile phone can reduce possible effects of the presence of an odd recording device and ensure the spontaneity of the interaction, especially among youngsters.

13 The generational division is partially based on the traditional sociolinguistic classification of age groups (Labov, 1972, also applied in the corpus PRESEEA as explained by Moreno Fernández, 1996). Two main differences apply to the current classification: an additional group (Gen1) is added (0-11), and the age limits of Gen2 (age group of 20-34 becomes 12-25) have been adapted, as the age of 12 is regarded as the approximate (psychological and biological) start of adolescence (Eisenstein, 2005). We implemented this adapted categorisation because one of the objectives of the analysis is exactly to capture innovative forms in the language of the second generation. Moreover, there is evidence that innovations often stagnate and stabilize at late adolescence, that is around the age of 25 (cf. model of Incrementation, Labov, 2001: 448).
} 


\subsection{Methodology}

A thorough search of all intensifying forms under investigation was carried out through a close reading of the entire CORMA. This bottom-up approach, although time-consuming, has the advantage of revealing new intensifying tendencies in their discursive context. Furthermore, this method allows a researcher to detect new, often low-frequency, intensifiers since it does not rely on previously listed forms. Taking into account the scope of this study (cf. Section 2), the data collection focused on syntagmatic intensification including intensifiers that modify another element "in praesentia" (Albelda Marco, 2007). This scope enables the creation of a comparative framework to survey age-based variation and patterns of recent language change. It thus comprises three intensifying strategies: (1) intensive prefixes (e.g. superdelgada 'very skinny', ultrarrealista 'very realistic'), (2) the suffixes with an augmentative or superlative value (e.g. ambientazo 'nice atmosphere', importantísimo 'really important') ${ }^{14}$, and (3) lexical intensifying items that modify a base ${ }^{15}$. Note that this study is not restricted to cases in which the modified element is an adjective (i.a. Aijmer, 2018; Bauer \& Bauer, 2002; Ito \& Tagliamonte, 2003; Lorenz, 2002; Paradis, 2000; Stenström, 1999; Stenström, 2000; Tagliamonte, 2008), but also includes other modified categories such as nouns, NPs, verbs or even vocatives (cf. Section 4 for more detailed examples). By taking a broader scope, this study aims to avoid an overly narrow conceptualization of intensification which would risk losing sight of the rich and language-specific creative mechanisms characterizing the Spanish intensifying system.

In the end, the search generated a corpus of over 446 morphological and lexical intensifiers, representing the speech of both male and female speakers living in the Spanish capital of Madrid, of different sociocultural levels and of different generations. Section 4 presents an inventory of the observed intensifying forms while Section 5 and 6 look into their generation specific use and the question of to what extent these observations may account for processes of linguistic change.

\section{Intensification strategies in present-day Madrilenian Spanish: an overview}

A general quantitative analysis of the corpus (Table 2) covers 245 cases $(55 \%)$ of suffixation, 131 cases of lexical intensification (29\%), and 70 cases (16\%) of prefixation of the base word.

\footnotetext{
14 The database was filtered manually to eliminate all tokens including a morphological element being part of a lexicalized word. The main criterion guiding this selection process was the appearance of these words as entries in the normative dictionary of the Real Academia Española (2014). Thus, for instance coñazo ('bothersome person') (a), incorporated in the RAE dictionary as a full lexical item, is excluded from the sample while temazo ('nice subject') (b), absent from the dictionary, is included.

(a) PEL3F1 porque es un coñazo ('because he is a disturbing person.')

(b) AM2M4 pero también es un temazo tío ('but it is also an important subject, dude.')

15 In his survey of intensification processes in Italian, Grandi (2017) also places both analytical (i.e. lexicalized collocations) and synthetic constructions (the superlative suffix -issimo) at the top of his cline of intensification.
} 


\begin{tabular}{|l|l|l|l|l|l|l|l|}
\hline \multicolumn{2}{|c|}{ Suffixation } & \multicolumn{2}{|l|}{ Prefixation } & \multicolumn{2}{|l|}{ Lexical item } & \multicolumn{2}{|c|}{ Total } \\
\hline$\#$ & $\%$ & $\#$ & $\%$ & $\#$ & $\%$ & $\#$ & $\%$ \\
\hline 245 & 55 & 70 & 16 & 131 & 29 & 446 & 100 \\
\hline
\end{tabular}

Table 2. General frequency of intensification strategies

In what follows, a more detailed description of the various intensification strategies is provided.

\subsection{Suffixation strategies}

The first category under consideration comprises suffixes with an superlative, augmentative or generally emphasizing value. In comparison with previous studies (e.g. Molina Martos, 2010 on intensifiers in the speech of young girls of Madrid who attested only -ísimo and -ote), our database gathers a more varied inventory of suffixes, listed below in descending frequency: ísimo (e.g. monísimo 'very cute') ( $\mathrm{n}=214 ; 87.5 \%)$, -azo (e.g. temazo 'important topic') ( $\mathrm{n}=19$; $8 \%$ ), -aco (e.g. golaco 'nice goal') ( $n=5 ; 2 \%)$, -ote (e.g. chavalotes 'really nice guys') $(n=3 ; 1 \%)$, -ón (e.g. jugadón 'a nice play') ( $\mathrm{n}=3 ; 1 \%$ ) and -ejo (e.g. palabras rarejas 'very weird words') $(n=1 ; 0.5 \%)^{16}$. In this list of six different suffixes, the high frequency of the superlative suffix ísimo immediately stands out (87.5\%). This prevalence has been attested in previous studies (Arce Castillo, 1999; Martínez López, 2009; Molina Martos, 2010; Stenström, 2005) and is now empirically confirmed for contemporary Madrilenian Spanish, although there are some generation-specific preferences (cf. Section 5 on age-based variation).

The intensifying suffixes can be bounded to different parts of speech. They primarily combine with adjectives (4a) $(n=177 ; 72 \%)$, but also modify adverbs $(4 b)(n=36 ; 15 \%)$, nouns $(4 c)(n=26 ; 11 \%)$ and even different grammatical categories with a vocative function $(n=6 ; 2 \%)$ $(4 d)$.

(4a) ROPAj3F1 Sí claro, no me extraña, es que es monísima. ('Yes of course, no wonder, it's extremely cute.')

(4b) 3F1 Lo habéis preparado tardísimo. ('You've prepared it very late.')

(4c) ROPAj3F1 Sí lleva faldas de este estilo, lleva vestidos. ('Yes, she wears skirts of this kind of style, she wears dresses.')

CROPA3F6 Tiene estilazo. ('She has a really nice style.')

(4d) PEL3F2 Hola guapísima, ¿cómo-? ('Hello very gorgeous, how-?')

CPEL2F1 ¿Qué taaal? ('How do you do?') ${ }^{17}$

\footnotetext{
${ }^{16}$ The specific values of these Spanish suffixes are highly context-dependent. Some morphemes are specialized exclusively in intensification, like the superlative suffix -ísimo (Albelda Marco, 2007: 54), while others encompass various meanings. The suffix -ejo, for instance, has by default a derogatory connotation but additionally encodes an intensifying value, which can be interpreted as a shift towards the negative pole of the semantic scale of intensity (cf. Section 2).

17 In this particular context, the adjective guapa (4d) fulfils the functional category of vocatives. Following AUTHOR 2 , vocatives are linguistic expressions whose prototypical function is to attract the attention of the interlocutor to whom the message is addressed. By using the suffix -ísima in this context, the speaker reaffirms the alliance with the interlocutor, reinforcing her image ("allo-reaffirmative intensification" in terms of Briz Gómez (2017: 53)).
} 


\subsection{Prefixation strategies}

Compared to the inventory of suffixes, the list of prefixes with an intensifying value is quite uniform, as it is restricted to the forms super- (e.g. superguay 'really cool') ( $n=69 ; 99 \%)$ and ultra- (e.g. ultrarrealista 'very realistic') $(n=1 ; 1 \%)^{18}$. This distribution corroborates the dominance of super- as the most frequent intensification prefix in Spanish colloquial conversations (Rodríguez Ponce, 2002; Stenström, 2005). Considering the almost complete absence of paradigmatic variability (Lehmann, 1985), it seems that the Spanish prefixation paradigm has become more grammaticalized than as described in the literature (Albelda Marco, 2007; García Platero, 1997; Martín García, 1998; Rodríguez Ponce, 2002). In order to gain further insight into how this might have occurred, we will take a closer look at the use of super- by different generations in Section 6 .

Super- is mostly combined with an adjective ( $n=57 ; 81 \%)(5 a)$, but can also modify adverbs $(n=13 ; 19 \%)(5 b)$. It can be used repeatedly with an increasing emphatic value (5a) (Bonacchi, 2017).

(5a) 3F2 pero es que Paul desde Francia está super super agobiado ('but Paul, in France, is really really overwhelmed.')

(5b) PEL3F2 Se comía super bien ahí eh ('One could eat extremely well there, eh.')

\subsection{Lexical strategies}

As mentioned before (cf. Section 2), the inventory of analytical constructions composed by a lexical intensifier modifying a base compose a creative and heterogeneous group of intensifying strategies with a high diversity in internal structure, productivity and expressive power. A more detailed description of these forms, their specific values and context-dependent interpretation would be highly interesting but goes beyond the limits of this article. As one of the main goals is to trace age-based variation and to monitor patterns of recent language change as to the composition of the paradigm, a well-considered quantitative perspective is adopted and preferred.

Table 3 gives an overview of all 21 lexical intensification strategies that were extracted from the CORMA corpus, in descending order of frequency.

\begin{tabular}{|l|ll|l|}
\hline Lexical item & $\#$ & $\%$ & Example corpus \\
\hline (un) montón (de) & 50 & $38 \%$ & un montón ha engordado ('he has put on a lot of weight') \\
\hline puto/a & 17 & $13 \%$ & la puta borrachera ('the fucking drunkenness') \\
\hline mazo (de) & 13 & $10 \%$ & mazo de amor ('a lot of love') \\
\hline bien & 8 & $6.25 \%$ & bien guapos ('really handsome') \\
\hline
\end{tabular}

\footnotetext{
18 In contrast to the limited spectrum of productive intensifying prefixes in Spanish, Napoli \& Ravetto (2017) attest a varied inventory and a growing productivity in contemporary Italian (a.o. arci-, extra-, iper-, mega-, super-, stra-, ultra-) and German (a.o. extra-, hyper-, maxi-, mega-, super-, ultra-).
} 


\begin{tabular}{|l|ll|l|}
\hline (una/la) cantidad de & 7 & $5.5 \%$ & la cantidad de amistades ('a lot of friendships') \\
\hline todo/a & 5 & $4 \%$ & vas todo retrasado ('you're very late') \\
\hline que te cagas & 4 & $3 \%$ & mola que te cagas (it's extremely cool') \\
\hline menudo/a & 4 & $3 \%$ & menuda mierda ('what a shit) \\
\hline de puta madre & 3 & $2.25 \%$ & ha ido de puta madre ('it's been fucking great') \\
\hline (un) mogollón (de) & 3 & $2.25 \%$ & los ha hecho un mogollón (he has done a lot for them') \\
\hline que te mueres & 3 & $2.25 \%$ & silba que te mueres ('he whistles extremely well') \\
\hline de/una mierda & 3 & $2.25 \%$ & cuatro colores de mierda ('four shitty colours') \\
\hline (un) cacho (de) & 2 & $1.5 \%$ & cacho escote ('an enormous cleavage') \\
\hline de (la) polla & 2 & $1.5 \%$ & un trabajo de la polla ('a shitty job') \\
\hline con locura & 1 & $0.75 \%$ & te quiero con locura ('I love you madly') \\
\hline un huevo & 1 & $0.75 \%$ & la crece un huevo ('she grows it a lot') \\
\hline un bledo & 1 & $0.75 \%$ & me importa un bledo ('I don't give a damn') \\
\hline del copón & 1 & $0.75 \%$ & un frío del copón ('a tremendous cold') \\
\hline por un tubo & 1 & $0.75 \%$ & millones por un tubo ('millons in large amounts') \\
\hline una barbaridad & 1 & $0.75 \%$ & he adelgazado una barbaridad ('I have slimmed down a huge amount') \\
\hline que lo flipas & 1 & $0.75 \%$ & una gran innovación que lo flipas ('an extremely great innovation') \\
\hline
\end{tabular}

Table 3: Distribution of lexical intensifiers

The survey includes lexical intensifiers that modify the propositional content of the base both from a quantitative (e.g. (un) montón (de), (un) mogollón (de), una barbaridad) and a qualitative (e.g. bien, menudo) point of view. It also comprises more subjective intensifiers that enable the speaker to express a specific negative or positive evaluation of the intensified base, depending on the context (e.g. puto, de puta madre, que te mueres). Additionally, the intensifiers seem to be recruited from different grammatical categories, like NPs (e.g. un montón ha engordado), subordinate clauses (e.g. una pinta que te cagas), adjectives (e.g. menuda situación) or adverbs (e.g. bien guapos). When they are turned into intensifying mechanisms, the original grammatical categories are recategorized, for example by the integration of the lexical item into a prepositional phrase (e.g. ha ido de puta madre). Depending on the modified base word, they acquire different functions, such as an adjectival (e.g. la puta borrachera) or adverbial (e.g. mazo famoso) one, or they turn into adverbial locutions (e.g. ha ido de puta madre) or nominal quantifiers (un montón ha engordado, la cantidad de amistades).

Moreover, the set of lexical intensifiers presented in Table 3 includes both more lexicalized (e.g. un bledo) and more grammaticalized (e.g. mazo) intensifying mechanisms. On the one hand, items such as un montón de, puto and mazo can best be described in terms of grammaticalization ${ }^{19}$. Mazo, for instance, originated from a (collective) noun and, through a process of grammaticalization including semantic bleaching, became a frequently used lexical

\footnotetext{
19 In the literature on English intensifiers (Aijmer, 2018; Lorenz, 2002; Tagliamonte, 2008), grammaticalization is often mentioned along with delexicalization, and defined as "the reduction of the independent lexical content of a word, or group of words, so that it comes to fulfil a particular function" (Partington, 1993: 138).
} 
intensifier in the language of young Madrilenian speakers, appearing in different contexts (by modifying adjectives, verbs and nouns -see AUTHOR for more details). The noun puto (literally 'whore') has undergone similar changes ${ }^{20}$. First, as an intensifier, it has lost its original meaning and after reanalysis it has acquired new semantic and pragmatic features (e.g. reflecting the speaker's emotion or attitude). Other typical features of grammaticalization include its high token frequency and the fact that, as a multifunctional intensifier, it modifies a wide variety of grammatical categories: it appears with nouns (e.g. el puto medio 'the fucking middle'), proper nouns (e.g. el puto Retiro 'the fucking Retiro park'), adjectives (e.g. puto asqueroso 'fucking disgusting') and even verbs (e.g. no me puto habla 'he doesn't fucking talk to me').

On the other hand, some intensifiers are subject to lexicalization, a process defined by Traugott (2010: 274) as "the use of a syntactic string or word-formation as a new contentful form that is semantically not fully compositional and is relatively idiosyncratic" 21 . Lexicalization generally implies a reduction of productivity, as items subject to this process appear within specific collocations and become less widely applicable (Himmelmann, 2004). In the Spanish corpus this can be observed with elements like un bledo, restricted to a combination with importar (e.g. importa un bledo but also importa mazo vs *un bledo majo but mazo majo, *un bledo de amor but mazo de amor). Be it as it may, a detailed description of the complete set of lexical intensifiers as the outcomes of different processes of linguistic change exceeds the limits of the current analysis, and is thus a matter for future studies.

In sum, the survey of intensifying strategies in the CORMA corpus of contemporary Madrilenian Spanish leads to some interesting interim conclusions. First, it appears that, despite the wide range of morphological resources available, two synthetic strategies stand out in particular: the suffix -ísimo and the prefix super-. Second, within the category of lexical strategies, many different items appear, including a series of hapaxes or one-offs. The first observation recalls one of Lehmann's (1985) criteria of grammaticalization, namely the reduction of paradigmatic variability or obligatorification, meaning that the choice among members within a paradigm becomes more constrained when involved in a process of linguistic change. On the other hand, it seems as if this tendency of morphological obligatorification is accompanied by an extension of the paradigm of lexical intensifiers.

\section{Age-based variation and use of intensifiers}

Whereas the status of intensifiers can depend on different parameters like register, regional origin, individual and stylistic variables (Grandi, 2017), this study exclusively focuses on age. The factor of age is indeed of growing importance for language choice and change. In concrete,

\footnotetext{
20 The process of grammaticalization of puto is similar to the evolution of the English intensifier fucking (Palacios \& Núñez, 2014).

${ }^{21}$ Grandi (2017) also refers to "fossilized" collocations which generally share a low degree of semantic compositionality but a high degree of internal cohesion.
} 
the distribution of intensifying mechanisms in different generations enables to monitor patterns of recent language change with an advanced cross-over of two methods and, as such, to further test the applicability of the Apparent-Time Construct (cf. Section 6). Furthermore, as regards the Spanish intensifying strategies there are no data available that present a finegrained analysis of intensifying preferences. Hence the question remains whether different generations use similar or different strategies, and whether the Spanish intensifying system also displays a 'spectacular generation gap', as has been observed for English (cf. Section 1).

It goes without saying that different life stages engender diverse linguistic behavior. While children (Gen1) are still achieving full language acquisition (Renn, 2011), adolescents (Gen2) are relatively free of normative pressures from the linguistic market, as generally reflected in higher rates of non-standard features and increased peer-group influence (Cheshire, 1987; Wagner, 2012). Following up on the idea that teenage talk is a catalyst for language change, preparing and indicating new trends (Molina Martos, 2010; Zimmermann, 2002), the present analysis seeks to provide insights into the ongoing change and "fashions" within the Madrilenian Spanish intensifying system. During adulthood (Gen3), speakers generally become more conservative, as they are affected by the pressure of mainstream society (Cheshire, 1987; Eckert, 1997). The oldest generation (Gen4) is the least studied age group of all and is also included in this analysis. The present study will check whether their language use is the most conservative one or whether the language of older, often retired, people reflects a weakening of the pressures to conform to societal norms (Cheshire, 1987). Besides the analysis of type differences according to the speaker's age (cf. Section 5.2), the study also aims to trace the token frequency and distribution of particular intensifiers (cf. Section 5.1).

\subsection{General frequencies}

Table 4 and Figure 1 present the frequency of the different mechanisms of intensification in the four generations per 1,000 words ${ }^{22}$. The data show a clear tendency according to which the relative frequency of intensifiers is inversely proportional to the age of the speaker: the younger the speaker, the more intensifiers (s)he integrates in his or her speech and vice versa.

\begin{tabular}{|l|l|l|l|}
\hline & \# words / subcorpus & \# absolute & $\begin{array}{l}\text { \# normalized } \\
\text { (/1,000 words })\end{array}$ \\
\hline Gen1 (0-11) & 12,536 & 34 & 2.71 \\
\hline Gen2 (12-25) & 41,844 & 85 & 2.03 \\
\hline
\end{tabular}

\footnotetext{
${ }^{22}$ As the number of words of collected speech is not equal for each generation, the frequencies are calculated proportionally, per 1,000 words in the subcorpus. If we take the example of Gen1, the following calculation was carried out: 34 (absolute frequency) / 12,536 (number of words Gen1) * 1,000 = 2.71 (normalized frequency). In 8 cases, the data do not provide information about the age of the speaker. These data are included in the calculation of the different types in intensifiers (cf. Table 2) but excluded from the analysis of the age-based variation.
} 


\begin{tabular}{|l|l|l|l|}
\hline Gen3 (26-55) & 170,313 & 240 & 1.41 \\
\hline Gen4 (+55) & 85,499 & 79 & 0.92 \\
\hline \multicolumn{3}{|c|}{ Table 4: normalized frequency of intensifiers per generation }
\end{tabular}

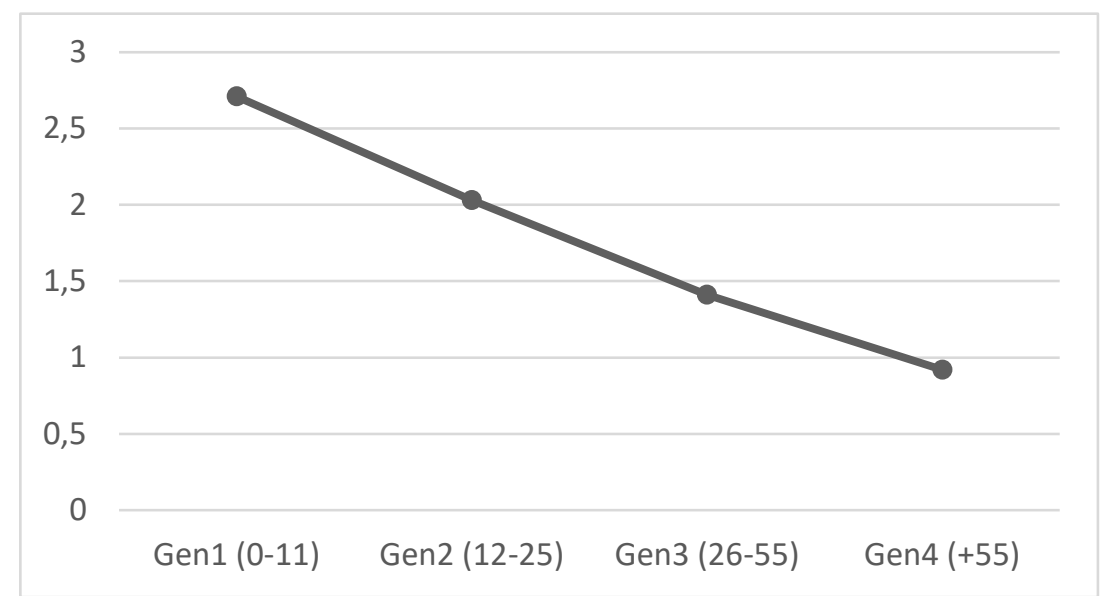

Figure 1: normalized frequency of intensifiers per generation per 1,000 words

The Two-proportions Z-Test shows that the generational differences are statistically significant. This test compares two observed proportions. We compared the proportion of Gen1 vs. Gen2, Gen2 vs. Gen3 and Gen3 vs. Gen4. The difference between the independent samples is statistically significant for each comparison, with $p<0.05$, apart from the comparison between Gen1 and Gen2 (Gen1 vs. Gen2: $p=0.1862$; Gen2 vs. Gen3: $p=0.004427$; Gen3 vs. Gen4: $p=0.001279$ ). The social factor of age thus has a significant impact on how often a speaker makes use of intensifiers.

Interestingly, our data differ from the attested tendency in some studies on the English intensifying system (Stenström et al., 2002; Palacios \& Núñez, 2012), that indicate a more frequent use of intensifiers such as very, completely or totally among adults. Still, we have to take into account that these studies focus exclusively on adjectival intensification. When intensifiers are more broadly studied as adverbs that boost the meaning of other clausal elements, the data reveal that intensifiers are much more frequent in younger speakers' talk than in older speakers' talk. Indeed, also in English the younger generations prefer other, more expressive intensifying forms such as fucking and bloody (Paradis, 2000: 154). Our data corroborate the assumption that Spanish youngsters, and apparently also children (Gen1) taking into account the relatively small subcorpus - resort more frequently to intensifying forms in their daily conversations than older generations do (Briz Gómez, 2003; Palacios \& Núñez, 2014).

\subsection{Correlation between intensifier type and age of the speaker}

In a next phase of the analysis, it is important to look for empirical evidence of the vitality and possibly different distribution of intensifying types (that is, by suffixation, prefixation or lexical 
items) in Madrilenian Spanish across generations. Table 5 shows that the correlation between generation and type of intensification is statistically significant. The Pearson's Chi-squared test of Independence presents a small $p$-value of $2.197 \mathrm{e}-13$ with $\mathrm{X}$-squared $=71.314 \mathrm{df}=6$. The Cramer's $V$ test points to a value of 0.2853 , which means that the effect of the correlation is moderate. Table 5 also mentions the values of the Standardized Residuals (SR $)^{23}$.

\begin{tabular}{|c|c|c|c|c|c|c|c|c|c|c|c|}
\hline & \multicolumn{2}{|c|}{ Suffixation } & \multirow[b]{2}{*}{ SR } & \multicolumn{2}{|c|}{ Prefixation } & \multirow[b]{2}{*}{ SR } & \multicolumn{2}{|c|}{$\begin{array}{l}\text { Lexical } \\
\text { items }\end{array}$} & \multirow[b]{2}{*}{ SR } & \multicolumn{2}{|c|}{ Total } \\
\hline & $\#$ & $\%$ & & \# & $\%$ & & $\#$ & $\%$ & & \# & $\%$ \\
\hline Gen1 & 29 & $85 \%$ & +2.4 & 4 & $12 \%$ & -0.56 & 1 & $3 \%$ & -2.86 & 34 & $100 \%$ \\
\hline Gen2 & 31 & $36 \%$ & -2.28 & 7 & $8 \%$ & -1.71 & 47 & $55 \%$ & +4.33 & 85 & $100 \%$ \\
\hline Gen3 & 122 & $51 \%$ & -0.83 & 57 & $24 \%$ & +3.23 & 61 & $25 \%$ & -1.21 & 240 & $100 \%$ \\
\hline Gen4 & 58 & $73 \%$ & +2.24 & 0 & $0 \%$ & -3.5 & 21 & $27 \%$ & -0.51 & 79 & $100 \%$ \\
\hline
\end{tabular}

These quantitative data lead to a number of interesting observations. First, intensification through augmentative and superlative suffixes (i.e. temazo, jugadón, guapísimo) is the strategy most frequently used by Gen1, Gen3 and Gen4. The Standardized Residuals show that this strategy is significantly overrepresented in the speech of Gen1 (+2.4) and Gen4 $(+2.24)$ and underrepresented in Gen2 (-2.28). Second, more differences arise regarding intensification through prefixation of the base word. While this strategy is rather frequently used by Gen3 ( $24 \%$; SR $=+3.23$ ), it does not appear in the speech of Gen4. Third, it stands out in the data that in more than half of the observed cases in Gen2 (55\%; SR $=+4.33)$, teenagers and young adults use lexical intensifying forms. They constitute the only generation that recurs more frequently to analytic intensifying strategies than synthetic ones. Still, the data do not point to a spectacular 'generation gap' in the intensifier paradigm. The picture that emerges is more like a continuum between alternating strategies, including some age-based preferences.

For once, although they are the most frequent users of intensifiers (cf. supra Section 5.1), compared to the other generations, Gen1 does not make use of age-unique intensifiers ${ }^{25}$. As regards the analytic intensifying strategies, only one intensifier appears, that is one occurrence of the lexical item (un) montón (de) (6). Besides the use of the prefix super-, their suffix

\footnotetext{
${ }^{23}$ The standardized residuals show which cells contribute the most to the significance of the chi-square test. Values greater than +2 indicate that the observed frequency is significantly higher than the expected frequency, while standardized residuals lower than -2 indicate that the observed frequency is significantly lower than the expected frequency. The higher the value of the residuals the greater the contribution (Levshina, 2015).

24 The number of speakers within each subsample (e.g. type: suffix; Gen: Gen2) always exceeds 5 different speakers, except for the Gen1 for prefixes (2 speakers) and lexical items (1 speaker). We argue that, except for these 2 particular cases in which the idiomatic language of the particular speakers could distort the interpretation of the data, the high number of speakers included within the other subsamples (between 5 and 36) avoids an idiosyncratic reading of the data.

${ }^{25}$ However, we have to take into account that the subcorpus for this generation is the smallest one, which could possibly influence the proportions.
} 
paradigm is a little more varied with -ísimo, -azo (7) and-aco. Thus, the data suggest that the inventory of intensifiers of young children is still limited and mainly includes intensifiers with a low degree of expressivity, especially compared to the creative inventory of lexical intensifiers used by Gen2.

(6) PEL3F1hi Sí yo también tengo un montón de hambre pero bueno ('Yes, I'm really hungry too but ok.')

(7) AM1M7 Qué golazo, ¿eh? ('What a goal, eh?')

Indeed, the younger generation from Madrid (Gen2) makes use of intensifying strategies mostly by using a wide range of lexical items $(55 \%$; $S R=+4.33)$. The appearance of 12 different lexical intensifiers in their speech corroborates their reputation as expressive and creative users of language. Besides being frequent users of intensifiers, they recur to a wide range of analytic intensifying constructions, regularly idiomatic, metaphorical and emotionally striking expressions (e.g. de puta madre, que lo flipas, un bledo). Their intensifying paradigm also includes vulgar and dysphemistic intensifiers, considered as typical features of teenage talk (Rodríguez González, 2002), like de la polla (8) or una mierda (9).

(8) AM2M10 imagínate un pibe, unas pibas que te hagan un- un trabajo de la polla y que encima te la- encima te dejen palabrejas en plan guías con metáforas y tal, tío ('Imagine a guy, some girls who make you an incredible work [lit 'a work of a dick'] and that on top of that they leave you curses like guides with metaphors and so on, dude.')

(9) AM2F3 ¿Qué más da? Si una vez que estemos muertos nos va a importar una mierda. ('What difference does it make? Like once we're dead we're going to give a shit.')

However, these stigmatized intensifying forms do not cause negative interpretations when used amongst peers. As stipulated in Section 2, they have passed through a process of semantic bleaching and function as expressive markers with additional pragmatic functions. That is, the main function of their frequent and creative use is to strengthen solidarity and group membership and to create social distance with respect to other generations (Mitkova, 2009). This means that the mere use of these forms functions as "linguistic clues to the identity and group membership of the speaker" (Lorenz, 2002: 143), i.e. it identifies a speaker as a member of a particular speech community. 
Gen2 also displays the most innovative way of intensifying and makes ample use of exclusive intensifiers ${ }^{26}$. More specifically, the corpus attests to the exclusive use of the more vulgar lexical intensifier puto/a $(n=17)(10)$ and mazo (de) $(n=13)(11)$.

(10) AM2M3 Vaya puta borrachera hemos cogido, ya no veo de cerca, ni de lejos, no veo na', de na', de na', pero aún pienso ('What a fucking drunk state we're in, I don't see nearby nor far, I don't see nothing, nothing, nothing, but I still think.')

(11) AM2F1 Es un chaval mazo majo, tío ('It's a really nice guy, dude.')

In (10) the adjectival intensifier puta is used to strengthen the assertion that they were really drunk. In (11) a girl uses the lexical adverb mazo to intensify the friendliness of 'some guy' she met $^{27}$. Thus, by using their own creative intensifiers, the young adults seem to distance themselves from the adult world and, through their innovative language use, they (unconsciously) modify the intensifier paradigm. However, in order to confirm this hypothesis, it is necessary to try and trace these innovations in adult speech and to verify if they are integrated in more standard language situations among older speakers (cf. infra Section 6).

Next, the adults of Gen3 are the speakers who use the most varied inventory of suffixes. Indeed, in their intensifying mechanisms they integrate the entire paradigm of observed suffixes, namely -ísimo ( $n=106 ; 87 \%)$, -azo ( $n=9 ; 7 \%)$, -ón $(n=3 ; 2 \%)$, -aco $(n=2 ; 2 \%)$, -ejo $(n=1 ; 1 \%)$ and -ote $(n=1 ; 1 \%)$. For instance, in (12), a female speaker, observing a sports match, intensifies the base word jugada by adding the augmentative suffix -ón.

(12) 3F1 ábrela, corre, corre, corre. ah- muy bien, muy bien, muy bien, qué jugadón.

('open it, run, run, run, ah, very good, very good, very good, what a game!')

The Madrilenian adults of Gen3 also recur with a remarkable frequency (i.e. in $24 \%$ of their intensifying acts; SR: +3.23$)$ to another synthetic mechanism, the prefix super-.

(13) CPEL3F7 Pero si tiene que ser superconsciente de que de que hay mucha gente así ('But you have to be superconscious that there that there are a lot of people like that.')

\footnotetext{
${ }^{26}$ Within this set of exclusive intensifiers, we only consider intensifiers that are relatively frequent and we do not take into account intensifiers with less than 5 occurrences in the corpus. This study thus verifies the use of exclusive intensifiers in teenage talk for Madrilenian Spanish. Similar results were found in the speech of their Englishspeaking counterparts within the study of Macaulay (2006). He attests the in-group use of the intensifiers pure and dead in the speech of adolescents in Glasgow.

${ }^{27}$ Although the analysis of other relevant factors like gender and social class are outside the scope of this study, some interesting remarks can be done on the social status of mazo (AUTHOR 3). A case-study on the rise and spread of this typical Madrilenian intensifier showed that throughout the $21^{\text {st }}$ century it has achieved a significant social diffusion, corresponding to a 'change from below' (Blas Arroyo, 2005; Eckert, 2003). The intensifier is widely spread in the speech of present-day high-class Madrilenian girls (8.92/10,000 words, corpus CORMA) while its use was rather exceptional in the speech of high-class young girls at the beginning of the $21^{\text {st }}$ century $(0.46 / 10,000$ words, corpus COLAm).
} 
Furthermore, adults make also use of a wide variety of lexical intensifiers (e.g. un frío del copón, un cacho de animal, he adelgazado una barbaridad) although in our data these forms are never exclusive for this generation.

Finally, the data suggest that the speakers of Gen4 rely more easily on more conventional and less expressive or creative forms. For instance, not surprisingly, the superlative suffix ísimo is the only suffix they use, and it is used in the large majority of the cases, namely in $73 \%$ of all intensification acts ( $S R=+2.24$ ). Regarding the lexical elements, as one would expect, more expressive intensifiers like de mierda, que te cagas or de puta madre do not appear in the language of the older Madrilenian speakers. The data thus seems to provide empirical evidence for the linguistic conservatism of the Gen4 in present-day Madrilenian Spanish. They instead resort marginally to more regular forms like un montón (14) or menudo (15).

(14) CON4F12 Ha engordado muchísimo. Porque la pusieron para que tuviera la menopausia, porque como viene de hormonas, dicen, y todo eso... O sea, un montón ha engordado ('She has put on a lot of weight. Because they put her to have menopause, because as it comes from hormones, they say, and all that... In other words, she has put on a lot of weight.')

(15) CPEL4F6 El barrio se llama barrio de Salamanca ('The neighbourhood is called Salamanca.')

CPEL4F5 menudo barrio ('What a neigbourhood.')

All in all, the corpus findings confirm that speakers of Gen4 also have high tendencies to intensify their speech, probably for pragmatic reasons of seeking attention. Still, they avoid recurring to typical expressions of Gen3 (their children) and certainly Gen2 (their grandchildren), which would go against their education and values. On the contrary, the data do show that the language of Gen3 is more influenced by the speech of their children (Gen2) as they more frequently engage in daily family conversations ${ }^{28}$.

\section{Patterns of recent language change}

Even within the life span of one generation, intensifying mechanisms of Madrilenian speakers are thus subject to change. In order to track processes of linguistic change within the phenomenon of intensification, two distinctive members of the intensifying paradigm, namely both the lexical intensifier mazo and the intensifying prefix super-, are subjected to closer inspection. To empirically verify if and how the use of these intensifying forms has changed in time, a fine-grained analysis is set up by crossing Real-time and Apparent-time evidences (cf.

\footnotetext{
${ }^{28}$ We thank an anonymous reviewer for pointing out this more general conclusion.
} 
Section 1). The case studies discover to what extent the Apparent-Time Construct is suitable for analysing recent language change within the paradigm of intensifiers, suggesting that the applicability of the construct may be linked to the specific nature (i.e. morphological versus lexical device) and sociopragmatic mark of the intensifying element (i.e. mazo being highly specialized in teenage talk, cf. Section 4).

The first intensifier under consideration is the typical Madrilenian intensifier mazo, an ageunique intensifier of Gen2 in the contemporary CORMA corpus. A recent study has provided evidence that mazo was already a highly frequent and versatile intensifier in teenage talk at the beginning of the twenty-first century (AUTHOR). These results were based on the COLAm corpus, Corpus Oral de Lenguaje Adolescente de Madrid (Universidad de Bergen), compiled between 2003 and 2007. The comparison of the language of young speakers in different time periods - the speakers of Gen2 of the corpus CORMA share comparable extra-linguistic characteristics and backgrounds with the speakers of Gen2 of the COLAm corpus $^{29}-$ shows $^{2}$ that this intensifier seems to endure in the language of successive generations of youngsters, although it becomes somehow less frequent: from 14.34 per 10,000 words in the COLAm corpus at the beginning of the $21^{\text {st }}$ century to 3.1 per 10,000 words in present-day teenage talk in CORMA.

That said, according to the Apparent-Time Construct, one would expect that, if individuals fix their speech patterns, it would also appear nowadays (thus in the CORMA corpus) in the language of Gen3, which was the former Gen2 at the turn of the $21^{\text {st }}$ century. However, the opposite situation occurs, as the form seems to have disappeared in present-day adult speech. Therefore, the cross-over between the Real-Time (comparing COLAm and CORMA) and Apparent-Time Analysis (Gen3 vs. Gen2 in CORMA) provides evidence that the case of the intensifier mazo could be considered as an example of age grading (Eckert, 1997; Wagner, 2012). The lexical intensifier seems indeed to be correlated to a particular life stage, that is, adolescence, and gets lost as speakers grow older. This tendency is repeated in successive generations, as shown by the Real-Time Analysis of Gen2 in respectively COLAm and CORMA. The data thus suggest that the expressive and age-exclusive intensifier is highly related to the younger life stage and serves as an linguistic marker of young identity. The expressive element, however, seems to disappear from a speaker's language when aging, as it may lose its in-group function. Therefore, the Apparent-Time Analysis does not seem the most appropriate construct to track recent language change of more expressive and marked intensifiers like mazo.

\footnotetext{
29 The subcorpus of conversations between youngsters (Gen2) of CORMA is collected through comparable methods as those of the COLAm corpus. The conversations are recorded under optimal conditions and constitute spontaneous, colloquial and dynamic interactions between teenagers. The young recruits (cf. supra Section 3.1) were responsible for recording conversations with friends and/or relatives of the same age group.
} 
Second, the Real-Time analysis (thus comparing COLAm and CORMA) of the prefix superin the language of Gen2 shows that at the beginning of the $21^{\text {st }}$ century, super-appears quite frequently in Spanish teenage talk (2.79/10,000 words) and is still used, albeit less frequently, in contemporary Madrilenian youth language (1.44/10,000 words in Gen2 CORMA). Following the Apparent-Time Construct, the teenagers of COLAm, roughly fifteen years ago, partially passed to the Gen3 of present-day Madrilenian Spanish. In the CORMA corpus, this age group still excels in the use of super- (Gen3: $24 \%$ vs. Gen1: $12 \%$ and Gen2: $7 \%$ ). A typical instance of this intensifying strategy is provided by case (16) in which the intensifying prefix par excellence is added both to the adjective bonito and the adverb bien.

(16) PEL3F2 El pueblo era super bonito, se comía super bien, barato. ('The village was really beautiful, one could eat really nice, cheap.')

This indicates that, as opposed to mazo, the morphological intensifier super- does not seem to be subject to age-grading, as present-day adults of Gen3 (thus Gen2 at the beginning of the century) still incorporate this element in their daily speech. This shows that intensification through prefixation is not subject to the process of age grading in the same way as more expressive lexical intensifiers. Therefore, we argue that age grading, and by extension the validity and applicability of the Apparent-Time Construct, might depend on the nature, degree of expressivity and social index of the intensifier.

Consequently, an Apparent-Time Analysis of super-can easily be conducted. The analysis of the distribution of super- in the four generations of CORMA points to a quantitative disproportion in its use. Super- is used by the speakers of Gen1 (12\% of their intensifying paradigm), Gen2 (7\%) and Gen3 (24\%) while speakers of the oldest generation Gen4 never make use of $\mathrm{it}^{30}$. The data thus suggest that the present-day Gen3 of Madrilenian speakers continue to use the prefix they already used as teenagers at the beginning of the $21^{\text {st }}$ century and have adopted this intensifier in their adult speech. Its rather neutral semantics seem to favor its survival and resistance to age grading. The Gen2 in CORMA still uses the prefix in $7 \%$ of their intensifying acts, but probably as a reaction to adults' language use, they use more expressive and generation-specific intensifiers. In addition, the absence of the prefix super- in the more conservative language of Gen4 can be considered as a reflection of an earlier linguistic stage providing us with information about the intensifier paradigm in a former language stage (from approximately 40-60 years ago). Consequently, the fact that Gen4 does not intensify by using the prefix super-, seems to indicate that super- is a quite modern prefix of intensification in Madrilenian Spanish.

\footnotetext{
30 The standardized residuals (Gen3: +3.26 (more than expected) vs. Gen4: -3.53 (less than expected)) also point to this analysis.
} 


\section{Discussion and Conclusions}

The above analysis leads to a number of interesting conclusions at a descriptive, methodological and theoretical level. First of all, the data offer empirical evidence of the vitality and distribution of intensification strategies in contemporary Madrilenian Spanish. The quantitative analysis of the formal variation within the intensifier group shows that suffixes are most frequently used, followed by lexical elements and prefixes. Within the morphological paradigm of intensifiers, two forms stand out, namely the superlative suffix -ísimo (87.5\%) and the prefix super- (99\%). This global prefix has an outstanding role in the speech of Madrilenian mid-life adults. Regarding the lexical items, the data reveal a varied and creative inventory of different forms, from neutral to more expressive forms, including some intensifiers with a taboo origin. The obligatorification of the morphological paradigm and the extension of the lexical paradigm have increased our interest in tracking processes of linguistic change within the phenomenon of intensification.

This study further compared the use of intensifiers in different generations to verify to what extent the paradigm has changed over the years. It first looked into the correlation between the generation and the type of intensifiers speakers prefer. The data showed that intensification is a linguistic phenomenon present in the speech of all generations, but the younger the speaker, the more intensifiers (s)he incorporates in his/her daily speech. However, the data do not point to a significant 'generation gap', but rather display a continuum with some clear agebased preferences. In general, Gen2 and Gen3 fall back on the widest list of intensifying forms. Moreover, the data corroborate the assumption that teenagers are linguistic innovators. Not surprisingly, this group makes use of the most expressive intensifiers and they constitute the only generation that resorts to exclusive forms of intensification, namely puto/a and mazo. This is in line with the generally accepted idea that teenagers' language use strengthens the shared group identity and allows them to create a so-called "linguistic counterculture".

In addition, this article investigated in more detail the recent language change of two intensifiers, mazo and super-, both different in formal (respectively, a lexical strategy and a prefix) and sociopragmatic nature (mazo being exclusively related to a younger life-stage). The two case studies have contributed to the question of how recent language change can best be studied methodologically, and, in particular, to the question of whether the Apparent-Time Construct is suitable for analyzing mid-term language change within the intensifying paradigm. First, the cross-over between the methodology of Real-Time Analysis and Apparent-Time Analysis showed that age-grading occurs more with expressive and socio-pragmatically more marked intensifiers like mazo. Concretely, this intensifier, which belongs to a more open and dynamic paradigm, is used by successive generations of teenagers but did not pass through into the speech of the next generations. Teenagers seem to abandon this form when they grow into adulthood. This may thus count as a proof of age-grading, and, to some extent, 
undermines the idea that the Apparent-Time Construct would be an accurate tool to explore language change in progress. Therefore, the study suggests that the validity and applicability of the Apparent-Time Construct might depend on the expressivity and the nature of the linguistic item under consideration. Indeed, when looking into the diachronic behaviour of the morphological prefix super-, it did seem to be an appropriate construct. This system-dependent and semantically more neutral form is less likely to be abruptly abandoned by the speakers when they grow into a new age group; thus, for this linguistic item, age-grading does not seem to apply. The high frequency of the prefix in the speech of Gen3 and its striking absence from the speech of older people suggests that super- is a quite modern prefix of intensification, trendy nowadays in adult speech and already slightly outdated in teenage talk.

\section{References}

Aijmer, K. (2018). That's well bad: Some new intensifiers in spoken in British English. In V. Brezina, R. Love, \& K. Aijmer (Eds.), Corpus Approaches to Contemporary British English (pp. 60-95). New York and London: Routledge.

Albelda Marco, M. (2007). La intensificación como categoría pragmática: revisión y propuesta: una aplicación al español coloquial. Frankfurt am Main: Peter Lang.

Arce Castillo, Á. (1999). Intensificadores en español coloquial. Anuario de estudios filológicos, 22, 37-48.

Athanasiadou, A. (2007). On the subjectivity of intensifiers. Language Sciences, 29, 554-565.

AUTHOR

AUTHOR2

AUTHOR 3

Bailey, G., Wikle, T., Tillery, J., \& Sand, L. (1991). The apparent time construct. Language variation and change, 3(3), 241-264.

Barbieri, F. (2008). Patterns of age-based linguistic variation in American English. Journal of sociolinguistics, 12(1), 58-88.

Bauer, L., \& Bauer, W. (2002). Adjective boosters in the English of young New Zealanders. Journal of English Linguistics, 30(3), 244-257.

Blas Arroyo, J. L. (2003). Perspectivas (socio)lingüísticas complementarias en el estudio de la variación y el cambio lingüístico en español. Estudios de Sociolingüística, 4(2), 653-692.

Blas Arroyo, J. L. (2005). Sociolingüística del español: desarrollos y perspectivas en el estudio de la lengua española en contexto social. Madrid: Cátedra.

Bolinger, D. (1972). Degree words. The Hague/Paris: Mouton.

Bonacchi, S. (2017). What does reduplication intensify?. In M. Napoli \& M. Ravetto (Eds.), Exploring Intensification: synchronic, diachronic and cross-linguistic perspectives. (pp. 289304). Amsterdam/Philadelphia: John Benjamins.

Bowie, D. (2005). Language change over the lifespan: A test of the apparent time construct. University of Pennsylvania Working Papers in Linguistics, 11(2), 45-58. 
Briz Gómez, A. (1996). Los intensificadores en la conversación coloquial. In A. Briz Gómez et al. (Eds.), Pragmática y gramática del español hablado (pp. 13-36). Zaragoza: Pórtico.

Briz Gómez, A. (1998). El español coloquial en la conversación: esbozo de pragmagramática. Barcelona: Ariel.

Briz Gómez, A. (2003). La interacción entre jóvenes. Español coloquial, argot y lenguaje juvenil. In M. T. Echenique Elizondo \& J. Sánchez Méndez (Eds.), Lexicografía y Lexicología en Europa y América (pp. 141-154). Madrid: Gredos.

Briz Gómez, A. (2017). Una propuesta funcional para el análisis de la estrategia pragmática intensificadora en la conversación coloquial. In M. Albelda Marco \& W. Mihatsch, Atenuación e intensificación en géneros discursivos (pp. 43-67). Madrid: Iberoamericana Vervuert.

Bybee, J. (2010). Language, Usage and Cognition. Cambridge: Cambridge University Press.

Cameron, R. (2005). Aging and Gendering. Language in Society, 34(1), 23-61.

Chambers, J. K. (2003). Sociolinguistics of Immigration. In D. Britain \& J. Cheshire (Eds.), Social Dialectology: Studies in Honour of Peter Trudgill (pp. 96-113), Amsterdam: John Benjamins.

Cheshire, J. (1987). Age and generation-specific use of language. In U. Ammon, N. Dittmar \& K. Mattheier (Eds.), Sociolinguistics: An introductory handbook of the science of language and society (pp. 760-767). Berlin: Mouton de Gruyter.

Díaz-Campos, M. (2014). Introducción a la sociolingüística hispánica. Malden: Wiley Blackwell.

Dressler, W. \& Merlini Barbaresi, L. (1994). Morphopragmatics: Diminutives and Intensifiers in Italian, German and Other Languages. Berlin: Mouton de Gruyter.

Eckert, P. (1997). Age as a sociolinguistic variable. In F. Coulmas (Ed.), The handbook of sociolinguistics (pp. 151-167). Oxford: Basil Blackwell.

Eckert, P. (2003). Language and adolescent peer groups. Journal of language and social psychology, 22(1), 112-118.

Eisenstein, E. (2005). Adolescência: definições, conceitos e critérios. Adolesc Saude, 2(2), 6-7.

Fiorentini, I., \& Sansò, A. (2017). Intensifiers between grammar and pragmatics: A lesson from a language contact situation. In M. Napoli \& M. Ravetto (Eds.), Exploring intensification: synchronic, diachronic \& cross-linguistic perspectives (pp. 173-192).

Amsterdam/Philadelphia: John Benjamins.

Fuentes Rodríguez, C. (2006). Operadores de intensificación del adjetivo: los cuantificadores escalares. Anuario de estudios filológicos, 29, 35-53.

García Platero, J. M. (1997). Sufijación apreciativa y prefijación intensiva en español actual. Lingüística Española Actual, 19(1), 51-61.

Grandi, N. (2002). Morfologie in contatto. Le construzioni valutative nelle lingue del Mediterraneo. Milano: Franco Angeli.

Grandi, N. (2017). Intensification processes in Italian. In M. Napoli \& M. Ravetto (Eds.), Exploring intensification: synchronic, diachronic \& cross-linguistic perspectives (pp. 55-77). Amsterdam/Philadelphia: John Benjamins. 
Herrero Moreno, G. (1991). Procedimientos de intensificación-ponderación en el español coloquial, Español actual: Revista de español vivo, 56, 39-52.

Himmelmann, N. P. (2004). Lexicalization and grammaticalization: Opposite or orthogonal? In W. Bisang, N. P. Himmelmann \& B. Wiemer (Eds.), What makes grammaticalization? (pp. 21-42). Berlin/New York: Mouton de Gruyter.

Ito, R., \& Tagliamonte, S. (2003). Well weird, right dodgy, very strange, really cool: Layering and recycling in English intensifiers. Language in society, 32(2), 257-279.

Jørgensen, A. M., \& Drange, E. M. (2012). La lengua juvenil de las metrópolis Madrid y Santiago de Chile. Arena Romanistica, 9, 74-96.

König, E. (2017). The comparative basis of intensification. In M. Napoli \& M. Ravetto (Eds.), Exploring intensification: synchronic, diachronic \& cross-linguistic perspectives (pp. 15-32). Amsterdam/Philadelphia: John Benjamins.

Labov, W. (1972). Sociolinguistic Patterns. Pennsylvania: University of Pennsylvania Press.

Labov, W. (2001). Principles of Linguistic Change, Volume 2: Social Factors. Oxford: Blackwell.

Lehmann, C. (1985). Grammaticalization: synchronic variation and diachronic change. Lingua e Stile, 20(3), 303-318.

Levey, D. (2008). Language change and variation in Gibraltar. Amsterdam/Philadelphia: John Benjamins.

Levshina, N. (2015). How to do linguistics with R: Data exploration and statistical analysis. Amsterdam/Philadelphia: John Benjamins.

Lorenz, G. (2002). Really worthwhile or not really significant? A corpus-based approach to the delexicalization and grammaticalization of intensifiers in Modern English. In I. Wischer \& G. Diewald (Eds.), New reflections on grammaticalization (pp.143-161). Amsterdam: John Benjamins.

Macaulay, R. (2006). Pure grammaticalization: The development of a teenage intensifier. Language Variation and Change, 18(3), 267-283.

Martín García, J. (1998). Los prefijos intensivos del español: caracterización morfosemántica. Estudios de Lingüística, 12, 103-116.

Martínez López, J. A. (2009). Lexical innovations in Madrid's teenage talk: some intensifiers. Pragmatics \& beyond. New series, 184, 81-93.

Méndez-Naya, B. (2008). Special issue on English intensifiers. English Language \& Linguistics, 12(2), 213-219.

Meyerhoff, M. (2011). Introducing sociolinguistics. London: Routledge.

Mitkova, A. (2009). El estilo comunicativo de los jóvenes. Círculo de Lingüística Aplicada a la Comunicación, 37, 21-44.

Molina Martos, I. (2010). Difusión social de una innovación lingüística: la intensificación en el habla de las jóvenes madrileñas. Oralia, 13, 197-214.

Moreno Fernández, F. (1996). Metodología del "Proyecto para el Estudio Sociolingüístico del Español de España y de América". Lingüística, 8, 257-287. 
Napoli, M., \& Ravetto, M. (2017). Ways to intensify: Types of intensified meanings in Italian and German. In M. Napoli \& M. Ravetto (Eds.), Exploring intensification: synchronic, diachronic \& cross-linguistic perspectives (pp. 327-352). Amsterdam/Philadelphia: John Benjamins.

Palacios Martínez, I. M., \& Núñez Pertejo, P. (2012). He's absolutely massive. It's a super day. Madonna, she is a wicked singer. Youth language and intensification: a corpus-based study. Text \& Talk, 32(6), 773-796.

Palacios Martínez, I. M., \& Núñez Pertejo, P. (2014). Strategies used by English and Spanish teenagers to intensify language: A contrastive corpus-based study. Spanish in Context, 11(2), 175-201.

Paradis, C. (2000). It's well weird: Degree modifiers of adjectives revisited: The nineties. In J. Kirk (Ed.), Corpora Galore: Analyses and Techniques in Describing English (pp. 147-160). Amsterdam/Atlanta: Rodopi.

Paradis, C. (2008). Configurations, construals and change: Expressions of DEGREE. English Language and Linguistics, 12(2), 317-343.

Partington, A. (1993). Corpus evidence of language change: The case of intensifiers. In M. Baker et al. (Eds.), Text and Technology: In Honour of John Sinclair (pp. 177-192). Amsterdam/Philadelphia: John Benjamins.

Peters, H. (1992). English boosters: Some synchronic and diachronic aspects. In G. Kellermann \& M. D. Morrissey (Eds.), Diachrony within synchrony: Language history and cognition (pp. 529-546). Frankfurt: Peter Lang.

Real Academia Española. (2014). Diccionario de la lengua española. 23ª edición. Barcelona: Espasa-Calpe.

Renn, J. (2011). Patterns of style in the language of African American children and adolescents. Proceedings of the 35th annual Boston University Conference on Language Development, 2, 513-525.

Rodríguez González, F. (2002). El lenguaje de los jóvenes. Barcelona: Ariel.

Rodríguez Ponce, M. I. (2002). La prefijación apreciativa en español. Cáceres: Universidad de Extremadura.

Silva-Corvalán, C. (2001). Sociolingüística y pragmática del español. Washington, DC: Georgetown University Press.

Stenström, A.-B. (1999). He was really gormless - She's bloody crap: Girls, Boys and Intensifiers. In H. Hasselgkrd \& S. Okesfjell (Eds.), Out of Corpora: Studies in Honour of Stig Johansson (pp. 69-78). Amsterdam/Atlanta: Rodopi.

Stenström, A.-B. (2000). It's enough funny, man: Intensifiers in Teenage Talk. In J. M. Kirk (Ed.) Corpora Galore: Analyses and Techniques in Describing English (pp. 177-190). Amsterdam: Rodopi.

Stenström, A.-B., Andersen, G., \& Hasund, I. K. (2002). Trends in teenage talk: Corpus Compilation, Analysis and Findings. Amsterdam: John Benjamins.

Stenström, A.-B. (2005). He's well nice - Es mazo majo: London and Madrid Teenage Girls' Use of Intensifiers. In S. Granath, J. Millander \& E. Wennö (Eds.), The Power of Words: Studies in Honour of Moira Linnarud (pp. 205-214). Karlstad: Karlstad University. 
Stenström, A.-B. (2017). Swearing in English and Spanish teenage talk. In K. B. Fágersten \& K. Stapleton (Eds.), Advances in Swearing Research: New languages and new contexts (pp. 157-182). Amsterdam: John Benjamins.

Tagliamonte, S. A. (2008). So different and pretty cool! Recycling intensifiers in Toronto, Canada. English Language \& Linguistics, 12(2), 361-394.

Traugott, E. C. (2010). Grammaticalization. In S. Luraghi \& V. Bubenik (Eds.), Continuum Companion to Historical Linguistics (pp. 269-283). London: Continuum Press.

Wagner, S. E. (2012). Age grading in sociolinguistic theory. Language and Linguistics Compass, 6(6), 371-382.

Wieling, M., Grieve, J., Bouma, G., Fruehwald, J., Coleman, J., \& Liberman, M. (2016). Variation and change in the use of hesitation markers in Germanic languages. Language Dynamics and Change, 6(2), 199-234.

Zimmermann, K. (2002). La variedad juvenil y la interacción verbal entre jóvenes. In F. Rodríguez González (Ed.), El lenguaje de los jóvenes (pp. 137-164). Barcelona: Ariel. 